\title{
CLINICAL EVALUATION OF HYPERIMMUNE SERUM FOR THE TREATMENT OF NEWCASTLE DISEASE IN INDIGENOUS LAYER BIRDS
}

\author{
M. S. Islam, M. S. Parvin, J. Akhter1, M. T. Islam*, M. P. Siddique² and \\ M. H. Rashid ${ }^{3}$ \\ Department of Medicine, Bangladesh Agricultural University \\ Mymensingh-2202 Bangladesh
}

\begin{abstract}
The efficacy of hyperimmune serum for the treatment of Newcastle disease (ND) was evaluated in indigenous birds. A total of 20 indigenous birds ( 3 to 4 months old) were divided into three groups, namely group $A(n=9), B(n=8)$ and $C(n=$ 3 ). Birds of all the groups were infected orally with $0.2 \mathrm{~mL}\left(106.5 \mathrm{EID}_{50} / 0.1 \mathrm{~mL}\right)$ of virulent Newcastle disease virus (NDV). Birds of group A were treated with hyperimmune serum (raised in chickens against NDV) @ $2 \mathrm{~mL} /$ bird IM after 6 hours of infection before commencement of clinical signs. Birds of group B received two doses of hyperimmune serum, first @ $2 \mathrm{~mL} /$ bird IV after commencement of clinical signs and second @ $3 \mathrm{~mL} /$ bird IM 5 hours after first dosing. Birds of group C served as infected control. Birds of group A did not show any clinical signs of ND except one $(11 \%)$. However, the only sick bird recovered after one repeat dosing of $1 \mathrm{~mL}$ hyperimmune serum. In group B, 87.5\% birds survived with two birds having nervous signs. Therefore, it may be concluded that hyperimmune sera was effective in preventing morbidity and mortality due to ND in birds when administered before or after commencement of the clinical signs. However, it is needed to conduct a field trial to explore the efficacy of hyperimmune sera raised both in chickens and rabbits.
\end{abstract}

Key Words: Hyperimmune serum, Newcastle disease, Efficacy, Indigenous birds, Rabbits

\section{INTRODUCTION}

Newcastle disease (ND) has been considered as one of the important viral diseases of poultry worldwide. It is an acute highly contagious viral disease of various species of birds of all age groups (Saif et al., 2008). The virulence of ND strains varies greatly with the host, but breed or genetic stock does not appear to have a significant affection on the susceptibility of chickens to the disease (Saif et al., 2008). ND is caused by a single stranded,

\footnotetext{
1 Upazila Livestock Office, Islampur, Jamalpur, Bangladesh

2 Department of Microbiology and Hygiene, Bangladesh Agricultural University, Mymensingh-2202, Bangladesh

${ }^{3}$ Department of Microbiology, Jhenidah Government Veterinary College, Jhenidah, Bangladesh ${ }^{*}$ Corresponding author (Email: taohid.bau@gmail.com)
} 
enveloped, negative sense RNA virus belonging to the genus Rubulavirus of subfamily Paramyxovirinae and family Paramyxoviridiae (Saif et al., 2008). It causes considerable economic losses to the poultry industry due to high morbidity, mortality, stress, decreased egg production and hatchability throughout the world (Alexander, 2000) including Bangladesh (Kafi et al., 2003). ND has been recognized as one of the major problems of the large and small poultry industries in Bangladesh (Islam et al., 1998; Rahman and Samad, 2003) and it causes up to $40-60 \%$ of total mortality among poultry population in Bangladesh (Talha et al., 2001). Due to its worldwide occurrence, ND drew the attention of research workers for an effective control programme. Vaccination along with strict biosecurity measures are considered as effective means for its control. Therefore, the practice of vaccination became a routine work throughout the world (Rahman et al., 2002). Vaccination as a means to prevent the disease is also routinely practiced in Bangladesh (Samad, 2000). However, outbreaks of ND have been occurring frequently due to failure of vaccination resulted from high level of maternal antibody titre in young chickens which neutralizes vaccine virus and heterogenous level of antibody titre in adult birds (Rahman et al., 2002). Unfortunately, the prognosis for this disease is poor, with nearly a 100 percent mortality rate in chickens, once infected (Saif et al., 2008). There is no treatment; however, injections of hyper-immune serum have been used to protect exposed pet birds before and/or after they become symptomatic (Reynolds and Maraqa, 2000; www.peteducation.com). The flocks which have great value and are irreplaceable because of their blood lines are of major concern as like as valuable pet birds. Therefore, in the control of Newcastle disease in such flocks, there would appear to be a place for the use of hyperimmune serum. For this purpose, the present study was aimed to evaluate the efficacy of hyperimmune serum for the treatment of Newcastle disease in indigenous birds.

\section{MATERIALS AND METHODS}

\section{Study place and study period}

The experiment was conducted in the Department of Medicine in collaboration with the Department of Microbiology and Hygiene, Faculty of Veterinary Science, Bangladesh Agricultural University, Mymensingh during the period from July 2011 to June 2012.

\section{Preparation of hyperimmune serum}

A total of 15 indigenous male birds of around 2-3 months of age and four New Zealand White rabbits (3-4 months old) were used for preparation of hyperimmune serum. All the birds and rabbits were purchased from local market and ICDDR, B, respectively. After acclimatization and deworming, all the birds were vaccinated thrice at 7 days interval with live attenuated NDV vaccine (Intervet) followed by a single administration of inactivated vaccine (Intervet) while rabbits were inoculated with inactivated vaccine (Intervet) only for 4 occasions. Blood samples were collected at different occasions of vaccination as well as after 10 days of last vaccination. Sera were separated and kept at $-20^{\circ} \mathrm{C}$ until use. 


\section{Determination of antibody titre}

The haemagglutination inhibition (HI) test was done to determine the antibody titre in sera samples. The HI test was conducted according to the procedure described by earlier researchers (Islam, 2010). The antibody titre in pool sera was found to be very low (HI titre 192) in rabbits. So the rabbit serum was not used for treatment purpose.

\section{Experimental infection of chickens with NDV}

A total of 20 indigenous layer birds ( 3 to 4 months old) were divided into three groups, namely A $(n=9), B(n=8)$ and $C(n=3)$. Each bird of all the groups was infected with 0.2 $\mathrm{mL}\left(106.5 \mathrm{EID}_{50} / 0.1 \mathrm{~mL}\right)$ of virulent field isolate of Newcastle disease virus (NDV) through oral route of inoculation (Jalil et al., 2009).

\section{Treatment with hyperimmune serum}

Birds of group A were treated with hyperimmune serum (HI titre 512) @ 2 mL/bird IM after 6 hours of infection before commencement of clinical signs. However, one bird received repeat dose of $1 \mathrm{~mL}$ hyperimmune serum IM as it showed clinical signs 20 hours postinfection. Birds of group B were treated with hyperimmune serum @ $2 \mathrm{~mL} /$ bird IV after commencement of clinical signs. As no improvement was observed, these birds received repeat dose of $3 \mathrm{~mL}$ hyperimmune serum IM 5 hours after first dosing. Birds of group C served as infected control. Birds were monitored twice daily for 15 days to record clinical signs (if any) and mortality. Birds those died were subjected to post-mortem examination.

\section{RESULTS}

Results of treatment of NDV inoculated birds with hyperimmune serum before showing clinical signs showed that all the birds except one did not show any clinical signs of ND. However, the only bird that showed clinical signs of depression, drowsiness, weakness, slight nasal and eye discharges and slight coughing completely recovered after repeat dosing of hyperimmune serum. Therefore, the survival rate in group A was $100 \%$ (Table 1). On the other hand, the survival rate was $87.5 \%$ in group B, treated with hyperimmune serum after commencement of clinical signs of ND. However, the protection rate was $62.5 \%$ as two birds survived with nervous signs like paralysis of legs wings and torticollis.

Table 1. Protective efficacy of hyperimmune serum for the treatment of Newcastle disease in indigenous layer birds

\begin{tabular}{|c|c|c|c|c|c|c|c|}
\hline \multirow[t]{2}{*}{ Groups } & \multirow[t]{2}{*}{$\begin{array}{l}\text { No. of } \\
\text { birds }\end{array}$} & \multicolumn{2}{|c|}{$\begin{array}{l}\text { Dose of hyperimune } \\
\text { serum }(\mathrm{ml} / \text { bird })\end{array}$} & \multirow{2}{*}{$\begin{array}{c}\text { No. of } \\
\text { birds } \\
\text { survived }\end{array}$} & \multirow[t]{2}{*}{$\begin{array}{l}\text { Survival } \\
\text { rate }(\%)\end{array}$} & \multirow{2}{*}{$\begin{array}{l}\text { No. of birds } \\
\text { completely } \\
\text { recovered\# }\end{array}$} & \multirow[t]{2}{*}{$\begin{array}{l}\text { Protection } \\
\text { rate }(\%)\end{array}$} \\
\hline & & $1^{\text {st }}$ dose & $2^{\text {nd }}$ dose & & & & \\
\hline A & 9 & 2 (IM) & $1(\mathrm{IM})^{*}$ & 9 & 100 & 9 & 100 \\
\hline B & 8 & 2 (IV) & 3 (IM) & 7 & 87.5 & 5 & 62.5 \\
\hline $\mathrm{C}$ & 3 & - & - & 0 & 0.0 & 0 & 0.0 \\
\hline
\end{tabular}

*Only one bird received $2^{\text {nd }}$ dose, \#Birds those were completely free from any clinical signs, IM = Intramuscular, IV = Intravenous 
The NDV inoculated control birds those did not receive any treatment with hyperimmune serum showed the typical clinical signs of greenish watery diarrhea, depression, drowsiness, nasal and eye discharges, coughing followed by death within two days of postinfection. The post-mortem lesions recorded in the dead birds were severe haemorrhages in the digestive tract particularly in the proventriculus, small intestine and caeca.

\section{DISCUSSION}

Passive immunization with hyperimmune sera generated against an organism or specific protein of an organism is one of the important means to prevent and control animal diseases (Van Rompay et al., 1998; Reynolds and Maraqa, 2000 and Nedbalcova et al., 2011). The use of anti-tetanus serum or tetanus immunoglobulin is widely known in human medicine (Stiehm et al., 1998). In ruminant medicine, antisera are prescribed in the treatment of some important bacterial diseases like anthrax, black quarter, haemorrhagic septicemia and tetanus (Radostits et al., 2007) though antisera against these diseases are not available in Bangladesh except anti-tetanus serum. The present study reports the possibility of use of hyperimmune sera in poultry against the deadly Newcastle disease. In the study, hyperimmune sera found to be effective in the protection of birds against ND. However, it was observed that the birds which treated with hyperimmune serum before commencement of clinical signs was very effective ( $100 \%$ protection in terms of mortality) than the birds which received hyperimmune serum after commencement of clinical signs $(87.5 \%$ protection rate in terms of mortality). To the best of our knowledge, no research works has been conducted or is in progress directly related to the use of hyperimmune sera in the treatment of ND in Bangladesh. However, the use of hyperimmune sera in the treatment of ND was reported elsewhere abroad (Reynolds and Maraqa, 2000; www.peteducation.com). Reynolds and Maraqa (2000) found that passive immunization with hyperimmune sera generated to specific Newcastle disease virus proteins conferred protection against NDV challenge. There are some reports on the use of hyperimmune sera in other animal species like goats. Ihemelandu et al. (1985) found that hyperimmune serum was very effective in reversing the process of the peste des petits ruminants (PPR) if administered at the fever stage but not in animals that had progressed past the fever stage. Based on a study, Islam et al. (2003) reported that when PPR infected goats were treated with antibiotic combined with hyperimmune serum, $68.75 \%$ recovered from the disease within 3 to 5 days of infection. However, Steven et al. (2012) reported that in highly pathogenic systemic influenza infections in human, the window for successful intervention by administration of hyperimmune serum is narrow.

\section{CONCLUSION}

In conclusion, hyperimmune serum was found very effective in preventing morbidity and mortality of birds due to Newcastle disease, which gave a clear indication of effective use of hyperimmune sera in the protection of birds against ND, particularly the valuable birds like 
breeder and pet birds. However, it is needed to conduct a field trial to explore the efficacy of hyperimmune sera raised both in chickens and rabbits.

\section{ACKNOWLEDGEMENT}

The authors gratefully acknowledge the financial support of Bangladesh Agricultural University Research System to carry out the research work.

\section{REFERENCES}

Alexander, D. J. 2000. Newcastle disease and other avian Paramyxoviruses. Rev. Sci. Tech., pp. 443-462. http:/ / www.peteducation.com/article.cfm?c=15+1829\&aid=2264, Accessed on 22 March 2011.

Ihemelandu, E. C., Nduaka, O. and Ojukwu, E. M. 1985. Hyperimmune serum in the control of peste des petits ruminants. Trop. Anim. Health Prod., 17: 83-88.

Islam, M. R., Giasuddin, M., Rahman, M. M. and Kafi, M. A. 2003. Antibiotic combined hyperimmune serum therapy for Peste des Petits ruminants infected goats. Bangl. J. Vet. Med., 1: 49-51.

Islam, M. R., Khan, M, Das, P. M. and Bari, A. S. M. 1998. Poultry diseases diagnosed at necropsy in 1997 and 1998 in the Department of Pathology of Bangladesh Agricultural University, Mymensingh. Proceedings of 5th BSVER Annual Scientific Conference held on 3-4 December, 1998 at Bangladesh Agricultural University, Mymensingh.

Islam, M. T. 2010. Preparation of infectious bursal disease virus vaccines with an indigenous isolate of Bangladesh and determination of their efficacy. A PhD Dissertation submitted to the Department of Microbiology and Hygiene, Faculty of Veterinary Science, Bangladesh Agricultural University, Mymensingh. p. 10.

Jalil, M. A., Samad, M. A. and Islam, M. T. 2009. Evaluation of maternally derived antibodies against Newcastle disease virus and its effect on vaccination in broiler chicks. Bangl. J. Vet. Med., 7: 296-302.

Kafi, M. A., Rahman, M. B., Amin, M. M., Islam, M. R., Rahman, M. M. and Rahman, M. K. 2003. Comparative serological responses and protection conferred by vaccination with V4HR and BCRDV in chickens. Bangl. J. Vet. Med., 1: 25-27.

Nedbalcova, K., Kucerova, Z., Krejci, J., Tesarik, R., Gopfert, E., Kummer, V., Leva, L., Kudlackova, H., Ondriasova, R. and Faldyna, M. 2011. Passive immunisation of post-weaned piglets using hyperimmune serum against experimental Haemophilus parasuis infection. Res. Vet. Sci., 91: 225-229.

Radostits, O. M., Gay, C. C., Hinchcliff, K. W., Constable, P. D. 2007. Veterinary Medicine. 10th edn., Saunders Ltd., Philadelphia.

Rahman, M. A. and Samad, M. A. 2003. Pattern of occurrence of single and concurrent disease associated with mortality in commercial chickens in Bangladesh. Bangl. J. Vet. Med., 1: 15-20.

Rahman, M. M., Bari, A. S. M., Giasuddin, M., Islam, M. R., Alam, J., Sil, G. C. and Rahman, M. M. 2002. Evaluation of maternal and humoral immunity against Newcastle disease virus in chicken. Int. J. Poult. Sci., 1: 161-163. 
Reynolds, D. L. and Maraqa, A. D. 2000. Protective immunity against Newcastle disease: the role of antibodies specific to Newcastle disease virus polypeptides. Avian Dis., 44: 138-144.

Saif, Y. M., Fadly, A. M., Glisson, J. R., Mcdougald, L. R., Nolan, L. K. and Swayne, D. E. 2008. Newcastle disease and other paramyxoviruses, in: Alexander, D. J., (Eds) Diseases of poultry, 12 ${ }^{\text {th }}$ edn, Ames, Iowa, USA, Blackwell Publishing.

Samad, M. A. 2000. An overview of livestock research reports published during the twentieth century in Bangladesh. Bangl. Vet. J., 34: 53-149.

Steven, R., Darry, M. and Deborah, M. 2012. The use of hyperimmune serum for severe influenza infections. Crit. Care Med., 40: 973-975.

Stiehm, E. R. 1998. Passive Immunization. in: Feigin, R.D. \& Cherry, J.D., (Eds) Textbook of pediatric infectious diseases, 4th edn, Copp. 2769-2802, Philadelphia, Pa: The W. B. Saunders.

Talha, A. F. S. M., Hossain, M. M., Chowdhury, E. H., Bari, A. S. M., Islam, M. R. and Das, P. M. 2001. Poultry disease occurring in Mymensingh district of Bangladesh. Bangladesh Vet., 18: 20-23.

Van Rompay, K. K., Berardi, C. J., Dillard-Telm, S., Tarara, R. P., Canfield, D. R., Valverde, C. R., Montefiori, D. C., Cole, K. S., Montelaro, R. C., Miller, C. J. and Marthas, M. L. 1998. Passive immunization of newborn rhesus macaques prevents oral simian immunodeficiency virus infection. J. Infect. Dis., 177: 1247-1259. 